\title{
Effect of Cold Stress on Milk Yield, Milk Composition and Some Behavioral Patterns of Simmental Cows Kept in Open Shed Barns
}

\author{
Emrah KAYGUSUZ¹, Filiz AKDAĞ ${ }^{2 *}$ \\ ${ }^{1}$ Republic of Turkey Ministry of Agriculture and Forestry, Merzifon Directorate of District Agriculture and Forestry, Amasya, Turkey \\ ${ }^{2}$ Ondokuz Mayis University, Faculty of Veterinary Medicine, Department of Animal Breeding and Husbandry, Samsun, Turkey
}

\begin{abstract}
The aim of this study was to determine effect of cold stress on milk yield, milk composition and some behavioural patterns of Simmental dairy cattle kept in open shed barns. In the present study, daily milk yield, milk content, somatic cell count (SCC) in milk and some behavioural patterns of Simmental dairy cattle during winter were determined. Besides, wind chill temperature (WCT) was calculated by using wind speed, temperature and relative humidity rate. In the present study, diffence between mean value of wind speed, temperature, relative humidity rate and WCT characteristics were proved as significant $(\mathrm{P}<0.01)$ depending on months in winter. Difference between mean value determined in months winter as for milk composition traits such as protein and total dry matter rate, and SCC were proved as significant $(\mathrm{P}<0.05)$. It was also confirmed that negative phenotypic correlation exists between milk fat and total dry matter rate, and WCT $(\mathrm{P}<0.05)$. There were also significant differences as for rate of incidence of behavioural patterns such as lying and walking during months winter $(\mathrm{P}<0.05)$. In conclusion, it was determined that cold stress affects protein and total dry matter rate in milk, SCC and behavior patterns such as lying and walking of Simmental dairy cattle.
\end{abstract}

Keywords: Dry Matter, Lying Behavior, Simmental, Wind Chill Temperature.

\section{$* * *$ \\ Açık Barınaklarda Yetiştirilen Simmental İneklerinde Soğuk Stresinin Süt Verimi, Süt Bileşimi ve Bazı Davranış Özelliklerine Etkisi}

ÖZ

$\mathrm{Bu}$ araştırma, Simmental ineklerde soğuk stresinin süt verimi, süt bileşimi ve bazı davranış özelliklerine etkisini belirlemek amacıyla yapılmıştır. Araştırmada, Simmental ineklerin kış mevsimindeki günlük süt verimi, sütün bileşimi, sütteki somatik hücre sayısı (SHS) ve bazı davranış özellikleri belirlenmiştir. Ayrıca, rüzgar hızı, çevre sıcaklığ1 ve bağıl nem oranı tespit edilerek rüzgar soğutma indeksi (RSI) hesaplanmıştır. Araştırmada, kış mevsimindeki aylara göre rüzgar hızı, çevre sıcaklığı, bağıl nem oranı ve RSİ özelliklerinin ortalama değerleri arasındaki fark önemli $(\mathrm{P}<0,01)$ olarak belirlenmiştir. Süt bileşimi özelliklerinden protein ve toplam kuru madde oranları ile SHS'nın kış aylarında belirlenen ortalama değerleri arasındaki farkın önemli $(\mathrm{P}<0,05)$ olduğu belirlenmiştir. Ayrıca, süt yağ ve toplam kuru madde oranının RSİ ile arasında negatif fenotipik korrelasyon olduğu saptanmıştır $(\mathrm{P}<0,05)$. Davranış özelliklerinden yatma ve yürüme davranışlarının kış aylarındaki oranlarının önemli düzeyde farklılık gösterdiği belirlenmiştir $(\mathrm{P}<0,05)$. Sonuç olarak, açık barınakta yetiştirilen Simmental ineklerde soğuk stresinin sütteki protein ve toplam kuru madde oranı ile SHS değerlerini ve yatma ve yürüme davranışlarını etkilediği belirlenmiştir.

Anahtar Kelimeler: Kuru Madde, Rüzgar Soğutma Isısı, Simmental, Yatma Davranışı.

To cite this article: Kaygusuz E. Akdăg F. Effect of Cold Stress on Milk. Yield, Milk. Composition and Some Behavioral Patterns of Simmental Cons Kept in Open Shed Barns. Kocatepe Vet J. (2021) 14(3):351-358

Submission: 14.06.2021 Accepted: 31.08.2021 Published Online: 02.09.2021

ORCID ID; EK: : 0000-0001-6984-8526, FA: 0000-0001-9142-9731

*Corresponding author e-mail: filizakdag@omu.edu.tr 


\section{INTRODUCTION}

Main environmental problem encountered by dairy cattle kept in free stall barns, semi-open barns and on pastures under low temperatures is cold stress. Relative humidity rate, wind speed and solar radiation affect felt temperature and may develop cold stress (Laven and Holmes 2008, Angrecka and Herbut 2015). Under critical temperatures, depending on breed, age, gender, hair mantle, skin structure, size, and body surface (Könyves et al. 2017) in short terms cattle try to cope with cold by showing behavioural and physiological alterations (Mutaf and Sönmez 1984, Demirören 2007). If exposure period gets longer and animals are unable to cope with preserving body heat, they tend to end struggle and it is inevitable for them to die as a result of hypothermia (Young 1983, Demirören 2007).

Cold stress causes increase of basal metabolism speed and increase in additional energy need. As a result, rumination, gastrointestinal system activity, feed and liquid transmission rate increases and digestion ends in shorter periods. That quick digestion results in decrease of energy level acquired out of feed intake (Bickert and Mattiello 2016). Because animals get use of energy derived from feed intake only at survival rate, yield decrease and behavioural changes occur (Broucek et al. 1991, Navratil et al. 2017).

Many studies were conducted in order to state effect of heat stress level on dairy cattle farming (Dikmen and Hansen 2009, Teke and Akdağ 2012, Ar1 2015, Benavides et al. 2018, Koç and Uğurlu 2019) and as a result; various indexes were developed making use of several variance such as dry bulb thermometer, wet bulb temperature, dew point, humidity rate, solar radiation and wind speed (Dikmen and Hansen, 2009, Koç and Uğurlu, 2019). However, the number of studies proving effect of cold stress on animals is rare compared to studies on heat stress thus it has been limited to index which determine effect of cold index. Wind chill index (wind chill temperature, WCT), cold stress index and cattle comfort index are used towards determination of cold stress level. Wind chill index was used on human towards specifying risk of freezing and effect of freezing on skin (Siple and Passel, 1945). Because the mentioned index is regarded insufficient for animals due to hair and wool factors, it has been adopted for animals as a result of many researches (Insley 1973, Broucek et al. 1991, Davis et al. 2003, Tucker et al. 2004, Van Laer et al. 2014).

The aim of this study was to determine effect of cold stress caused by climatic factors during winter season in Simmental cows on milk yield, milk composition and some behavioral patterns.

\section{MATERIAL and METHODS}

The study was conducted on Simmental cow kept in a private dairy cattle enterprise in Amasya, Turkey. Totally 24 cows included in the scope of the study were randomly selected among Simmental cows equally on their early lactation period and first three lactation number. No changes were made in the husbandry-feeding conditions of the chosen cows and the regimes of the farm were applied. Diets were consisting of ration of $19 \%$ crude protein and 2700 $\mathrm{kcal} / \mathrm{ME} 10 \mathrm{~kg}$ dairy cattle feed per animal $24 \mathrm{~kg}$ corn silage, $3 \mathrm{~kg}$ trefoil and $4 \mathrm{~kg}$ hay, and water intake was designed ad libitum. The study was conducted in a free stall barn dairy cattle enterprise where shelters were designed as open shed. The enterprise was formed as open shed for young animals and dairy cows where animals rest, lie down where feeding racks and waterers were situated, and a range area for animals to stroll. Inside of the open shed area was divided by shapes, and automatic non-freezing waterers usable from both sides were placed between the sections. Feeders were installed under the roofed part along the open shed area. The range area of animals including feeders was connected to the open shed area and was surrender by shape fence.

In order to determine daily milk yield and milk composition, morning milking amounts were recorded periodically montly during winter. Milking operation was conducted by a nonfixed milking machine and individually each cow's milk yield was recorded by the milker. After milking of each cow, homogen sample of $40 \mathrm{ml}$ was directed to sterile sample vessel. Samples were put into sterile sample vessels in chemical tablets that prevent microbial growth without affecting milk composition and somatic cell count. The milk samples were transported to the laboratory under controlled coldchain conditions $\left(+4^{0} \mathrm{C}\right)$. Before analysis, milk samples were heated up to $40^{\circ} \mathrm{C}$ in water bath on the purpose of determining milk fat, protein, lactose and dry matter rate, and freezing point and somatic cell count of milk. Milk analysis were realised via Combi 150 analysis machine, using Flow cytometry analysis, and which is formed with integration of somatic cell counting machine and milk composition measurement machine (Akdağ et al. 2017).

Behaviours of cows were recorded every 15 days by a digital camera as to determine lying, feeding, standing and walking behaviours during winter. Two different 24-hour recording night vision cameras were placed viewing cows under examination and animal behaviours were recorded for 30 minutes on three different periods; after sunrise, at noon and before sunset (approximately at the same hours). During winter totally for 12 hours, 1.5 hours for each day recordings were obtained. After watching the records behavioural rates lying, feeding, standing and walking 
were calculated follows (Gastelen et al. 2011, Graunke et al. 2011).

Daily mean dry bulb thermometer, relative humidity rate and wind speed values which belong to enterprise area for 2019 December, 2020 January and February were obtained from district meteorological directorate. In order to calculate daily mean value of wind chilling index referred for measurement of cold stress WCT $=13.12+0.6215$ Tair-13.17 V0.16+ 03965 Tair $V^{0.16}$ equivalent, reported by Angrecka and Herbut, (2015) was referred. In this equivalent; WCT stands for wind chilling temperature $\left({ }^{0} \mathrm{C}\right)$, Tair stands for air temperature $\left({ }^{0} \mathrm{C}\right)$ and $\mathrm{V}$ stands for wind speed $(\mathrm{km} / \mathrm{h})$.

\section{Statistical Analysis}

Non-normally distributed SCC data was logarithmically transformed to $\log _{10}$ SCC. While comparing daily mean environmental temperature, relative humidity rate, wind speed, WCT, and milk yield and composition on monthly basis, one-way analysis of variance was used. Duncan test was referred in order to determine importance control of difference between the groups. In order to determine correlation between climatic characteristics and milk yield and milk composition, correlation test was applied and as to determine phenotypic correlation factor, Pearson correlation test was referred. So as to compare behavioural rates such as lying, standing, walking and feeding, chi square test was used. All calculations and analyses were performed with the SPSS package (version 21).

\section{RESULTS}

The results of the mean values of some climatic traits measured in winter and standard errors are shown in Table 1. Difference determined in December, January and February between mean value of wind speed, environmental temperature, relative humidity rate and WCT index traits was proved as significant $(\mathrm{P}<0.01)$. Mean values of wind speed were determined as 1.13, 0.77 and 1.47 in terms of $\mathrm{m} / \mathrm{s}$, and general mean value was determined as $1.12 \mathrm{~m} / \mathrm{s}$ during December, January and February.

Mean values and standard errors of daily milk yield milk composition and SCC of Simmental cows kept in open shed barns are presented in Table 2. Difference between mean values determined in December, January and February as for milk composition traits such as protein and total dry matter rate, and SCC was proved as significant $(\mathrm{P}<0.05)$.

Phenotypic correlation coefficient between climatic traits and milk yield, milk composition and SCC are presented in Table 3. It was determined that while positive correlation exists between milk fat and total dry matter rates and wind speed $(\mathrm{P}<0.05)$, there exists negative phenotypic correlation with WCT index $(\mathrm{P}<0.05)$.

Percentage of some behavioural patterns of Simmental cows kept in open shed barns recorded in winter are presented in Table 4. Difference of behavioural patterns of percentage lying, feeding, standing and walking in December, January and February was determined to be significant $(\mathrm{P}<0.01)$. In addition, when the behaviors by months were compared, the difference between the rates of lying and walking behaviors was found to be statistically significant

$(\mathrm{P}<0.05)$.

Table 1. Mean values and standard errors of some climatic traits in the winter $(\overline{\mathrm{x}} \pm \mathrm{Sx})$

\begin{tabular}{lcllll}
\hline \multirow{2}{*}{ Traits } & \multicolumn{3}{c}{ Months } & \multirow{2}{*}{ P-value } & \multirow{2}{*}{ Overall } \\
\cline { 2 - 5 } & December & January & February & \multirow{2}{*}{ Average } \\
\hline Wind speed $(\mathrm{km} / \mathrm{h})$ & $4.09 \pm 0.36^{\mathrm{b}}$ & $2.78 \pm 0.33^{\mathrm{c}}$ & $5.32 \pm 0.35^{\mathrm{a}}$ & 0.001 & $4.07 \pm 0.20$ \\
Temparature $\left({ }^{0} \mathrm{C}\right)$ & $4.67 \pm 0.49^{\mathrm{a}}$ & $1.75 \pm 0.38^{\mathrm{b}}$ & $3.12 \pm 0.82^{\mathrm{ab}}$ & 0.003 & $3.18 \pm 0.33$ \\
Relative humidity $(\%)$ & $73.39 \pm 1.85^{\mathrm{a}}$ & $73.77 \pm 1.42^{\mathrm{a}}$ & $67.57 \pm 2.52^{\mathrm{b}}$ & 0.049 & $71.58 \pm 1.13$ \\
WCT $\left({ }^{0} \mathrm{C}\right)$ & $-8.14 \pm 1.96^{\mathrm{b}}$ & $-6.98 \pm 1.31^{\mathrm{b}}$ & $-4.94 \pm 1.63^{\mathrm{a}}$ & 0.002 & $-10.02 \pm 0.96$ \\
\hline
\end{tabular}

a,b,c Different letters in the same row and for the same trait indicate a statistically significant difference $(\mathrm{P}<0.01)$. 
Table 2. Mean values and standard errors of daily milk yield, milk composition and somatic cell count of Simmental cows in the winter $(\overline{\mathrm{x}} \pm \mathrm{Sx})$

\begin{tabular}{lcccc}
\hline \multirow{2}{*}{ Traits } & \multicolumn{3}{c}{ Months } & Overall \\
\cline { 2 - 4 } & December & January & February & Average \\
\hline Daily milk yield (kg) & $9.41 \pm 0.55$ & $9.23 \pm 0.49$ & $9.38 \pm 0.46$ & $9.34 \pm 0.28$ \\
Fat (\%) & $3.62 \pm 0.13$ & $3.57 \pm 0.15$ & $3.70 \pm 0.06$ & $3.63 \pm 0.07$ \\
Protein (\%) & $3.54 \pm 0.07^{\mathrm{a}}$ & $2.94 \pm 0.07^{\mathrm{c}}$ & $3.22 \pm 0.02^{\mathrm{b}}$ & $3.23 \pm 0.04$ \\
Lactose (\%) & $4.97 \pm 0.05$ & $5.06 \pm 0.04$ & $4.92 \pm 0.04$ & $4.98 \pm 0.02$ \\
Total dry matter $(\%)$ & $13.33 \pm 0.17^{\mathrm{a}}$ & $12.45 \pm 0.17^{\mathrm{b}}$ & $13.03 \pm 0.08^{\mathrm{a}}$ & $12.94 \pm 0.09$ \\
${\text { Freezing point }\left({ }^{0} \mathrm{C}\right)}$ & $0.55 \pm 0.001$ & $0.55 \pm 0.001$ & $0.55 \pm 0.001$ & $0.55 \pm 0.001$ \\
SCC $^{1}$ & $4.37 \pm 0.13^{\mathrm{c}}$ & $5.32 \pm 0.05^{\mathrm{b}}$ & $5.62 \pm 0.08^{\mathrm{a}}$ & $5.12 \pm 0.08$ \\
SCC $^{2}$ & 74590 & 245913 & 562416 & 301376 \\
\hline
\end{tabular}

${ }^{a, b, c}$ Different letters in the same row and for the same trait indicate a statistically significant difference $(\mathrm{P}<0.05), \mathrm{SCC}^{1}: \log _{10}$ somatic cell count; $\mathrm{SCC}^{2}$ : somatic cell count $(\mathrm{pcs} / \mathrm{ml})$

Table 3. Phenotypic correlation coefficients among milk yield, milk composition and climatic traits.

\begin{tabular}{lcccc}
\hline Traits & Wind speed & Temparature & Relatif humidity & WCT \\
\hline Daily milk yield & 0.005 & 0.042 & -0.138 & 0.042 \\
Fat & $0.243^{*}$ & -0.050 & 0.141 & $-0.271^{*}$ \\
Protein & 0.221 & 0.137 & -0.176 & -0.132 \\
Lactose & -0.200 & -0.212 & 0.009 & 0.067 \\
Total dry mater & $0.260^{*}$ & -0.020 & -0.087 & $-0.251^{*}$ \\
Freezing point & -0.092 & $-0.298^{*}$ & 0.025 & -0.059 \\
SCC & -0.131 & -0.224 & 0.174 & 0.027 \\
\hline
\end{tabular}

SCC: $\log _{10}$ somatic cell count, WCT: Wind chill temperature; $*: \mathrm{P}<0.05$ 
Table 4. Percentages of some behavioural patterns of Simmental cows in the winter (\%)

\begin{tabular}{lcccc}
\hline \multirow{2}{*}{ Traits } & \multicolumn{3}{c}{ Months } & \multirow{2}{*}{ P-value } \\
\cline { 2 - 4 } & December & January & February & \\
\hline Lying & $30.61^{\mathrm{a}, \mathrm{A}}$ & $15.67^{\mathrm{b}, \mathrm{B}}$ & $15.32^{\mathrm{c}, \mathrm{B}}$ & 0.046 \\
Feeding & $39.82^{\mathrm{a}}$ & $43.08^{\mathrm{a}}$ & $45.26^{\mathrm{a}}$ & 0.850 \\
Standing & $23.45^{\mathrm{a}}$ & $23.71^{\mathrm{b}}$ & $29.93^{\mathrm{b}}$ & 0.497 \\
Walking & $6.12^{\mathrm{b}, \mathrm{B}}$ & $17.54^{\mathrm{b}, \mathrm{A}}$ & $9.49^{\mathrm{c}, \mathrm{B}}$ & 0.037 \\
\hline P-value & 0.001 & 0.001 & & \\
\hline
\end{tabular}

${ }^{\mathrm{A}, \mathrm{B}}$ The means with different superscript in each row are significantly different $(\mathrm{P}<0.05)$
${ }_{\mathrm{a}, \mathrm{b}, \mathrm{c}}$ The means with different superscript in each column are significantly different $(\mathrm{P}<0.01)$.

\section{DISCUSSION}

Daily mean wind speed for winter was specified as $4.07 \mathrm{~km} / \mathrm{h}(1.12 \mathrm{~m} / \mathrm{s})$, environmental temperature as $3.18^{\circ} \mathrm{C}$ and relative humidity rate was specified as 71.58. Besides, difference of mean values of wind speed, heat and relative humidity rate depending on months were proved as remarkable. During the periods when environmental temperature is low, wind speed being below $0.2-0.3 \mathrm{~m} / \mathrm{s}$ is important in respect to health and yield of cattle especially kept in open barns (Mutaf and Sönmez, 1984). As to this study it was specified that mean daily wind speed determined for each month exceeded the recommended value suitable for cattle kept in open shed barns. It was stated by several studies (Akçapınar and Özbeyaz 1999, Angrecka and Herbut 2015, Navratil et al. 2017, Koç and Uğurlu 2019) that for dairy farming enterprises thermal comfort necessary for animals in order to sustain living activities without decrease in yield should be between $-5^{0} \mathrm{C}$ and $25^{\circ} \mathrm{C}$. In the present study, monthly average environmental temperature for cattle reported is in line with the thermal comfort stated above. Moreover, daily average relative humidity rate reported was in line with the optimal humidity rates of $60-75 \%$ for animals stated by Uzal (2008) and, Bickert and Mattiello (2016).

In the present study mean WCT values in winter were stated between $-6.98^{\circ} \mathrm{C}$ and $-14.94^{\circ} \mathrm{C}$, and it was established that WCT in February reached its peak value (coldest environmental temperature) compared to other months. Even though environmental temperature in February was recorded as $3.12^{0} \mathrm{C}$, felt temperature by animals was stated as $-14.94^{\circ} \mathrm{C}$. In accordance with these results, considering only environmental temperature, cattles were exposed to comfort thermal but according to WCT values, felt temperature values were under comfort thermal values. Besides, it can be derived that environmental temperature in February felt by animals due to wind and humid was at critical threshold (NRC 1981). In a study on different cattle breeds in Sweden it was reported that whereas environmental temperature measured in December, January and February were $1.4^{0} \mathrm{C}$ and $-3.3^{0} \mathrm{C}$, values felt by animals were reported as $-2.7^{\circ} \mathrm{C}$ and $-7.6^{\circ} \mathrm{C}$ (Graunke et al. 2011). In a study conducted on Holstein cows in New Zeland, Tucker et al. (2004), reported environmental temperature inside shelter as $-1.2^{0} \mathrm{C}$, but it was reported as $-1.9^{0} \mathrm{C}$ outside the shelter, and WCT values of these measurements were reported respectively as $-1.3^{0} \mathrm{C}$ and $-9.9^{\circ} \mathrm{C}$.

In the present study, values of daily milk yield, milk fat, freezing point and lactose rate of milk obtained from Simmental cows measured during winter months were similar, however milk protein and total dry matter values recorded were lower in January, in which environmental temperature was recorded lowest, than other months. Alpan and Aksoy (2015) stated that milk protein rate could change depending on winter period and low levels of energy in ration. Bryant et al. (2007), Laven and Holmes (2008), Bickert and Mattiello (2016) reported that milk yield and composition could vary depending on decrease in environmental temperature, and notably protein and 
milk dry matter could decrease as well. Unlike this study, in some other studies it was reported that milk fat and protein rates increased during winter and autumn period when environmental temperature was low (Jenkins and Mc Guire 2006, Özek 2015).

When the phenotypic correlation coefficients between climatic traits, which is one of the results of this study, and milk yield, milk composition and SCC were analysed, it was stated that while correlation between milk fat and total dry matter rate, and wind speed was positive; correlation between these parameters and WCT index was negative. It can be deduced from these results that decrease in milk fat and total dry matter rate may depend on increase in WCT index, and decrease in wind speed. These two climatic traits have perverse effect on milk fat rate and total dry matter rate. Wind chilling index proves total effect of environmental temperature, humidity rate and wind speed, and this index expresses environmental temperature felt by animals. Negative increase of this index is an indicator for decrease in environmental temperature felt by animals. For this reason, taking WCT index into consideration in terms of change in milk fat and total dry matter rate is regarded more beneficial. In some studies, it was expressed that low environmental temperature may cause acceleration of basal metabolism and completion of digestion in shorter time thus as a result of decrease in energy intake obtained via forage, decrease in milk protein rate and milk fat rate could occur, accordingly same decrease in total dry matter could be recorded (Akçapinar and Özbeyaz 1999, Bryant et al. 2007, Laven and Holmes 2008, Bickert and Mattiello 2016).

In the present study, general mean of SCC of Simmental cattle was recorded as 301376 piece $/ \mathrm{ml}$ in winter and it was determined that SCC increased from December to February. Özkan (2017) determined SCC as 253.000 piece $/ \mathrm{ml}$ in winter and from summer toward winter increasing numbers of somatic cell were recorded. Dinçel and Dikmen (2013) stated that seasonal change in weather temperature causes variation in milk somatic cell count. Barkema et al. (1999) stated that there could be many factors along with seasonal changes such as lack of implementation of biosecurity rules, lactation period, milking hygiene, inefficiency in milking methods, layout plan of barn, floor of barn, inefficiency and instability of nutrition were influential on change in somatic cell count.

Animal behaviour is an important factor to establish animal yield and welfare level. In the present study, Simmental cow were observed in terms of feeding, lying, standing and walking behaviours and it is specified that in December among behavioural patterns mostly observed ones were feeding $(39.82 \%)$ and lying (30.61\%). As for January and February unlike December, mostly observed behaviour following feeding was standing. In discordance with this study, Koçyiğit (2014) reported that first two behaviours of intensive dairy cattle were lying (45\%) and feed intake (26\%). Mostly recorded behaviour that was affected from low environmental temperature was feed intake. Indeed, Çavuşoğlu (2016) reported that factors such as low environmental temperature, high humidity and wind speed increases need for energy and also stated that animals feed intake increases as a result of need for more heat generation. Graunke et al. (2011) also reported that wind and low environmental temperatures make difference on animal behaviours and based on feed intake behaviour, rumination frequency increases during the periods WCT index are recorded low.

When animal behaviours were compared in respect to months, it was determined that difference between rates of lying and walking behaviours was significant and lying behaviour in December was recorded more frequently compared to other months. Walking behaviour was recorded more frequent in January compared to other months. In the present study it is estimated that percantages of lying behaviour to have been reported in December and walking behaviour to have been reported in January was related with climatic factors such as rain and snow. While records were analysed in the study, it was specified that rainfall in December was quite less compared to other months; on the other hand snow fall was recorded in January. Luymes (1994) stated that because of wet floor due to low environmental temperature and rain, rate of animal lying behaviour decreased. Uzal (2008) reported that rate of resting-lying behaviour of animal decreased during extreme cold weather in winter depending on increase in physical activities and feed intake, on the other hand rate of standing increased. In the same study, it was also reported that wet barn floor affected lying duration, standing and feed intake behaviours of animals and they preferred to stand other than lying in order to balance their body heat. Kelly (2003) specified that due to frozen floor as a result of low environmental temperature animals had difficulty in walking thus, they acted other behavioural patterns more frequently than feed intake.

\section{CONCLUSION}

In conclusion, this study proved that WCT index calculated by means of wind speed and environmental temperature was higher in February compared to other months, which means environmental temperature felt by animals was the lowest in February. Besides, it was determined that cold stress is effective on milk protein rate, total dry mater rate, somatic cell count, lying and walking behaviour of Simmental cow kept in open shed barns. In line with the results of the present study, it was concluded that taking rain fall into consideration would result in more precise conclusions about effects of cold stress on different yield characteristics such as milk yield, 
fertility and growth, and more researches should be conducted on various species and breeds in order to specify limits of cold stress.

Acknowledgements: The authors also thank Prof. Dr. Ömür KOÇAK for assistance in milk analysis.

Financial Support: This study was supported by the Scientific Project Office of Ondokuz Mayis University, Samsun Turkey (PYO.VET.1904.20.001). This research article was summarized from the first author's master's thesis

Ethics Committee Information: This study is not subject to the permission of HADYEK in accordance with Article $8(\mathrm{k})$ of the "Regulation on Working Procedures and Principles of the Animal Experiments Ethics Committees". In addition, the authors have declared that Research and Publication Ethics are observed.

Conflict of Interest: The authors declare that there is no actual, potential or perceived conflict of interest for this article.

\section{REFERENCES}

Akçapınar H, Özbeyaz C. Hayvan Yetiştiriciliği Temel Bilgileri. Kariyer Matbaacilik, Ankara. 1999.

Akdağ F, Uğurlu M, Gürler H, Teke B, Koçak O. The relationships between udder traits and milk yield, milk composition, and subclinical mastitis in Jersey cows. Large Animal Review, 2017; 23(6): 203-209.

Alpan O, Aksoy AR. Sı̆̆ır Yetiştiriciliği ve Besiciliği, 7. Bask1, Favori Basım Yayın ve Matbaacılık, İstanbul. 2015.

Angrecka S, Herbut P. Conditions for cold stress development in dairy cattle kept in free stall barn during severe frosts. Czech J Anim Sci. 2015; 60(2): 81-87.

Ar1 UÇ. Sığırlarda 1sı stresinin fizyolojik ve hormonal olarak üremeye etkisi. J Reprod Artif Insemin-Special Topics, 2015;1(1):1-10.

Barkema HW, Van der Ploeg JD, Schukken YH, Lam TJGM, Benedictus G, Brand A. Management style and its association with bulk milk somatic cell count and incidence rate of clinical mastitis. J Dairy Sci. 1999; 82:1655-1663.

Benavides RAM, Guerrero HS, Atzori AS. A conceptual model to describe heat stress in dairy cows from actual to questionable loops. Acta Agron. 2018; 67(1): 59-64.

Bickert WG, Mattiello S. Stress in Dairy Animals: Cold Stress: Management Considerations. In: Smithers G, editör in chef. Reference module in food sciences. 1. Edition, Amsterdam, Elsevier. 2016; 1-7.

Broucek J, Letkovicova M. Kovalcuj K. Estimation of cold stress effect on dairy cows. Int J Biometeorol. 1991; 35:29-32.

Bryant JR, Lopez Villalobos N, Pryce JE, Holmes CW, Johnson DL. Quantifying the effect of thermal environment on production traits in three breeds of dairy cattle in New Zealand. New Zealand Journal of Agricultural Research, 2007; 50:327-338.

Çavuşoğlu YS. Ruminant hayvanlarda beslenme davranışları. Yüksek Lisans Tezi, Namık Kemal Üniversitesi Fen Bilimleri Enstitüsü, Tekirdağ, 2016.
Davis MS, Mader TL, Holt SM, Parkhurst AM. Strategies to reduce feedlot cattle heat stress: Effects on tympanic temperature. Journal of Animal Sci. 2003;81: 649-661.

Demirören E. Hayvan Davranışları. 2. Baskı, Ege Üniversitesi Ziraat Fakültesi Yayınları, İzmir. 2007; 1-250.

Dikmen, S, Hansen, PJ. Is the temperature-humidity index the best indicator of heat stress in lactating dairy cows in a subtropical environment. J Dairy Sci. 2009; 92:109-116.

Dinçel D, Dikmen S. Süt sı̆̆ırlarında sıcak stresinin tespiti, verim özellikleri üzerine etkileri ve korunma yöntemleri. Uludağ Univ J Fac Vet Med. 2013; 32(1):19-29.

Gastelen S, Westerlaan B, Houwers DJ, Eerdenburg FJCM: A study on cow comfort and risk for lameness and mastitis in relation to different types of bedding materials. J Dairy Sci. 2011; 94:4878-4888.

Graunke KL, Schuster T, Lidfors LM. Influence of weather on the behaviour of outdoor-wintered beef cattle in Scandinavia. Livestock Science, 2011; 136:247-255.

Insley LW. Wind chill effect. Master Thesis, Kansas State Universty Manhattan, USA, 1973.

Jenkins TC, Mc Guire MA. Major advances in nutrition: impact on milk composition. Journal of Dairy Science, 2006; 89: 1302-1310.

Kelly JM. Managing the feedlot in the cold. Çeviri: Ay S, Çınar H. 2003. https://www.trouwnutrition.com.tr/conten tassets/5ad87435a1d34111bb0d24d2c5a878b9/ruminantkatk-servisler/katki_bulten2003-04.pdf. Accessien date: 10.06.2021.

Koç HU, Uğurlu M. Süt sığırlarında 1sı stresinin verim özellikleri üzerine etkisi, Lalahan Hay Araşt Enst Derg. 2019; 59(1): 30-35.

Koçyiğit R. Farklı zemin tiplerinin esmer sığırlarda süt verimi ve süt kompozisyonu ile bazı davranış özellikleri üzerine etkileri. Doktora Tezi, Atatürk Üniversitesi Fen Bilimleri Enstitüsü, Erzurum, 2014.

Könyves T, Zlatkovic N, Memisi N, Lukac D, Puvaca N, Stojsin M, Halasz A, Miscevic B. Relationship of temperature-humidity index with milk production and feed intake of Holstein-Frisian cows in different year seasons. Thai J Vet Med. 2017; 47(1):15-23.

Laven RA, Holmes CW. A review of the potential impact of increased use of housing on the health and welfare of dairy cattle in New Zealand. New Zealand Veterinary Journal, 2008; 56(4):151-157.

Luymes J. Free stall design. British Columbia of Agriculture and Food Ministry, Farm Structures Factsheet, 1994;1-13.

Mutaf S, Sönmez R. Hayvan Barınaklarında İklimsel Çevre Denetimi. 3. Bask1, Ege Üniversitesi Ziraat Fakültesi Yayınları, İzmir. 1984.

Navratil S, Falta D, Chladek G. Effect of temperature cumulation on milk yield of Czech Fleckvieh-Simmental Cattle. Acta Universitatis Agriculturae et Silviculturae Mendelianae Brunensis, 2017; 65(5):1579-1584.

NRC. Effect of Enviroment on Nutrient Requirements of Domestic Animals. National Acad. Pres, Washington DC, 1981; 1-21.

Özek K. Süt sı̆̆ırlarında süt kompozisyonunu etkileyen faktörler ve besleme-süt kompozisyonu ilişkisi. Bahri Dağdaş Hayvancilık Araştırma Dergisi, 2015; 4(2):37-45.

Özkan M. Süt sığırlarında somatik hücre sayısının süt bileşimi ve kalitesine etkisi. Yüksek Lisans Tezi, Namı Kemal Üniversitesi Fen Bilimleri Enstitüsü, Tekirdağ. 2017.

Siple PA, Passel CF. Measurements of dry atmospheric cooling in subfreezing temperatures. American Philosophical Society, 1945; 89:177-199.

Teke B, Akdağ F. The effect of heat stress on some reproductive traits in Jersey cows under semi-humid 
conditions in Turkey. Bulgarian Journal of Agricultural Science, 18(4): 506-510, 2012.

Tucker CB, Weary DM, Fraser D. Free-Stall dimensions: effects on preference and stall usage. J Dairy Sci. 2004; 87:1208-1216.

Uzal S. Serbest ve serbest duraklı süt sığırı barınaklarında hayvanların alan kullanımı ve zaman bütçesine mevsimlerin etkisi. Doktora Tezi, Selçuk Üniversitesi Fen Bilimleri Enstitüsü, Konya. 2008; 1-197.

Van Laer E, Moons CPH, Sonck B, Tuyttens FAM. Importance of outdoor shelter for cattle in temperate climates. Livestock Science, 2014; 159:87-101.

Young BA. Ruminant cold stress: Effect on production. J Anim Sci. 1983; 57:1601-1607. 